\title{
Gonadotrophin, total oestrogen and progesterone concentrations in the plasma of lactating sows with particular reference to lactational oestrus
}

\author{
R. T. Duggan*†, M. J. Bryant* and F. J. Cunningham $\ddagger$ \\ Departments of *Agriculture and Horticulture, and $\ddagger$ Physiology \& Biochemistry, \\ University of Reading, Reading, Berkshire, U.K.
}

\begin{abstract}
Summary. Plasma concentrations of LH, FSH, progesterone and total oestrogens were determined (by radioimmunoassay) throughout late pregnancy and lactation in samples taken by cardiac catheter from 10 Camborough hybrid sows. At 2-3 weeks post partum, 5 were housed individually with their litters (Group I) and 5 grouped with their litters, a boar being introduced 1 day later (Group II).

Plasma progesterone fell 1-2 days pre partum and oestrogens at parturition, each remaining low in early lactation. Plasma $\mathrm{LH}$ was undetectable in most samples in this period, but FSH fell slightly during parturition, showing signs of resurgence from Day 10 post partum.

Group I sows remained in lactational anoestrus until weaning. In Group II there was increased plasma LH activity, and all Group II sows displayed oestrus during lactation. Only one farrowed to service at the lactational oestrus; of the remainder, oestrus in one was clearly anovulatory, and in two others was incomplete or atypical judged by plasma progesterone concentration. The data suggest that whilst oestrus can be induced by appropriate lactation management, poor conception rates to service at this oestrus may be due to the absence or impairment of ovulation.
\end{abstract}

\section{Introduction}

The period of lactation between parturition and weaning in the sow is usually considered to be infertile (Polge, 1972). Oestrus unaccompanied by ovulation occurs in a proportion of sows within 5 days of the peak of plasma oestrogen of feto-placental origin that occurs at parturition (Holness \& Hunter, 1975), but no further oestrous activity is observed until 3-7 days after weaning. Lactational anoestrus in the sow is characterized by a suppression of ovarian follicular growth and of accompanying uterine development and is associated with a low content of luteinizing hormone ( $\mathrm{LH})$ and a high content of follicle-stimulating hormone (FSH) in the anterior pituitary gland (Lauderdale, Kirkpatrick, First, Hauser \& Casida, 1965; Palmer, Teague \& Venzke, 1965; Crighton \& Lamming, 1969). The concentrations of LH, oestrogen and progesterone in plasma are low throughout this period (Molokwu \& Wagner, 1973; Ash \& Heap, 1975; Baldwin \& Stabenfeldt, 1975; Parvizi, Elsaesser, Smidt \& Ellendorff, 1976).

Attempts to reduce the interval between successive pregnancies by exogenous hormone therapy (e.g. Heitman \& Cole, 1956) or by partial separation of sow and litter (e.g. Smith, 1961; Crighton, 1970), or by a combination of both (Crighton, 1970) have met with mixed success. U.K.

† Present address: Department of Zoology, University College of North Wales, Bangor, Gwynedd LL57 2UW, 
Inhibition of follicular growth is said to be most marked in early lactation but diminishes with time (Polge, 1972). Early weaning systems have provided a more popular practical method of reducing the farrowing interval and weaning at 3-4 weeks post partum is now common commercial practice.

There have, however, been several reports in the farming press of oestrus in suckling sows (e.g. Boughton, 1967; Phelps, 1969) and more recently this has been investigated in depth (Rowlinson, Boughton \& Bryant, 1975; Petchey \& Jolly, 1979). The grouping of sows with their litters in early lactation, the presence of a boar and ad-libitum feeding from the time of grouping are each factors in the stimulation of oestrus during lactation (Rowlinson \& Bryant, 1976), and in combination have resulted in a $100 \%$ incidence of lactational oestrus, with $85 \%$ of the sows conceiving to first service (Rowlinson et al., 1975). Management during lactation is, therefore, clearly able to overcome the otherwise inhibitory influence of the suckling stimulus, but the means by which this is achieved are unknown.

The hormonal events associated with oestrous cyclicity in the pig have been documented (Stabenfeldt, Akins, Ewing \& Morrissette, 1969; Tilson, Erb \& Niswender, 1970; Henricks, Guthrie \& Handlin, 1972; Parvizi et al., 1976; Vandalem, Bodart, Pirens, Closset \& Hennen, 1979; Dusza \& Krzymowska, 1979), but the endocrine status of the lactating sow during induced lactational oestrus is quite unknown.

We therefore measured plasma concentrations of $\mathrm{LH}, \mathrm{FSH}$, oestrogen and progesterone in sows during late pregnancy and lactation.

\section{Materials and Methods}

\section{Animals and management}

Ten multiparous Camborough hybrid sows weighing between 200 and $250 \mathrm{~kg}$ were brought into the surgery at an estimated 5 days pre partum. An indwelling catheter was introduced into an ear vein by an aseptic surgical procedure modified from those of Anderson \& Elsley (1969) and Ash, Banks, Broad \& Heap (1972). Briefly, sows were sedated with $20-25 \mathrm{ml} 4 \%$ (w/v) azaperone (Stresnil: Janssen Pharmaceutica, Beerse, Belgium) injected intramuscularly together with $75 \mathrm{mg}$ atropine sulphate before induction of anaesthesia with a mixture of halothane, nitrous oxide and oxygen administered by open circuit. An ear was shaved and cleaned as described by Ash et al. (1972), and a polythene (Portex Plastics Ltd, Hythe, U.K.) or polyvinyl (Dural Plastics Pty, Dural, Australia) catheter ( $1.5 \mathrm{~mm}$ o.d.) containing heparinized $0.9 \%(\mathrm{w} / \mathrm{v})$ $\mathrm{NaCl}(500$ i.u. $/ \mathrm{ml})$ was inserted through a 14-gauge thin-wall needle (Butterfly-14: Abbott Laboratories, Chicago, U.S.A.) into a prominent ear vein. The catheter, total length 150-180 $\mathrm{cm}$, was advanced until the distal end abutted a heart valve $(\sim 60-75 \mathrm{~cm})$, when blood could no longer be drawn into a syringe. It was then withdrawn $5 \mathrm{~cm}$ and secured in place with sutures under and around the ear vein. The whole ear was then swathed in zinc oxide and the free end of the catheter, plugged with a stainless steel pin, was exteriorized in a pouch fashioned in the plaster where it could be coiled and stored safely between samplings. Finally, two polythene ear tags were inserted through the bandaged ear since experience has shown that adhesion between plaster and ear may be lost after a period of several weeks. After surgery, sows were returned to conventional farrowing pens on a University farm.

This preparation was sufficiently robust to withstand considerable piglet interference, but did on occasion require repair or replacement. At such times, sows were anaesthetized on site with a combination of $4 \%$ azaperone and $5 \%$ metomidate hydrochloride (Hypnodil; Janssen Pharmaceutica) delivered via the catheter; induction, bandage repair or replacement and recovery from anaesthesia were completed within $45 \mathrm{~min}$.

One sow (No. 211) received 3 foster piglets after farrowing in an attempt to standardize litter size. 
Approximately 16 days after farrowing (15.8 $\pm 2 \cdot 1$ (s.e.m.) days), 5 sows and their litters were removed from the farrowing house to be penned individually with their litters and with no boars in the immediate vicinity (Group I). The remaining 5 sows were moved as a group at 18.2 \pm 1.3 (s.e.m.) days post partum to a large covered straw yard, and a boar was introduced $24 \mathrm{~h}$ later (Group II). Blood $(8-10 \mathrm{ml})$ was taken daily at 12:00 h from surgery until allocation to groups; samples were then taken every $6 \mathrm{~h}$ at 06:00, 12:00, 18:00 and 24:00 $\mathrm{h}$ and continued until the end of oestrus in all Group II sows. In 5 Group II sows blood samples were also taken $20 \mathrm{~min}$ before and after movement from the farrowing house to investigate acute effects of movement per se on hormone titres. Blood samples were taken from catheters by syringe, transferred to heparinized centrifuge tubes and the plasma separated by centrifugation within 30 min of sampling the first sow. Plasma samples were stored at $-20^{\circ} \mathrm{C}$ until assay. Ear vein catheters were flushed and refilled with sterile heparinized saline $(250 \mathrm{i} . \mathrm{u} . / \mathrm{ml} 0.9 \% \mathrm{NaCl})$ and plugged.

Sows were fed four times daily $(2 \mathrm{~kg}$ ration) at each sampling period after allocation to groups. The occurrence of oestrus was defined by one or more of the following criteria: an observed service; 'riding marks' on the back of the female; vulval changes commonly associated with oestrus, such as colour, size and presence of any discharge, and evidence of the vulval labia having been opened by intromission; and the immobilization in response to hand pressure on the haunches of the sow.

The young were weaned at approximately 42 days post partum.

\section{Radioimmunoassays}

Steroid hormone concentrations were determined in plasma samples taken at 3-day intervals in the period from insertion of catheters to allocation of sows to Group I or II, and daily or 12 -hourly samples thereafter. Gonadotrophin concentrations were determined in all samples taken, i.e. in daily samples until allocation to groups, and 6-h samples thereafter until the end of oestrus in all Group II sows.

Progesterone. Plasma progesterone concentrations were measured by a method modified from that of Furr (1973), but using a different antiserum (No. 465/2). This is of similar specificity to No. 465/3 (Walton, McNeilly, McNeilly \& Cunningham, 1977). Plasma (200 $\mu$ l aliquots) was extracted once with 10 volumes light petroleum (b.p. $40-60^{\circ} \mathrm{C}$ ) which extracted $69.0 \pm 1 \cdot 27 \%$ (s.e.m., $n=90$ ) of $\left[1,2,6,7-{ }^{3} \mathrm{H}\right]$ progesterone (sp. act. $81 \mathrm{Ci} / \mathrm{mmol}$; Radiochemical Centre, Amersham, U.K.) added to a pool of plasma. In the absence of unlabelled hormone, 500

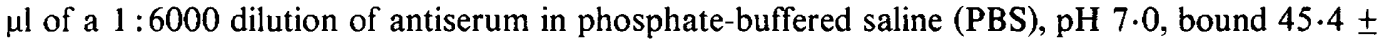
$0.8 \%(n=16)$ of $\left[{ }^{3} \mathrm{H}\right]$ progesterone $\left(\mathrm{B}_{\mathrm{o}}\right)$. Assay blanks consistently produced less displacement of $\left[{ }^{3} \mathrm{H} \mid\right.$ progesterone than the lowest standard concentration used; i.e. were $<0.125 \mathrm{ng} / \mathrm{ml}$. The coefficients of variation within and between assays were 10.1 and $15.6 \%$ respectively, using a pool of plasma containing an estimated $1.41 \pm 0.05 \mathrm{ng} / \mathrm{ml}$. Progesterone added to this pool $(0.4-16.0 \mathrm{ng} / \mathrm{ml}$ ) was quantitatively recovered (equation of linear regression was $y=1.025 x+$ $0.119 ; r=0.936)$. The concentration of hormone required to displace $10 \%$ of bound, labelled hormone $\left(B / B_{0}=90 \%\right)$, a measure of assay sensitivity, was $0.082 \mathrm{ng} / \mathrm{ml}$.

Total oestrogens. Plasma ( $200 \mu$ aliquots) was extracted once with 10 volumes diethyl ether, which extracted $83.8 \pm 2 \cdot 1 \%(n=40)$ of $\left[2,4,6,7-{ }^{3} \mathrm{H}\right]$ oestradiol $-17 \beta$ (sp. act. $85 \mathrm{Ci} / \mathrm{mmol}$; Radiochemical Centre) added to a pool of plasma. Ether extracts, and standard dilutions of oestradiol (Sigma, Poole, U.K.; 3.1-200 pg/50 $\mu \mathrm{l}$ ethanol), were evaporated to dryness in glass assay tubes and redissolved in $500 \mu \mathrm{l}$ aliquots of diluted anti-oestradiol serum $(510 / 6$; supplied by Dr B. J. A. Furr) containing approximately 8000 c.p.m. $\left[{ }^{3} \mathrm{H}\right]$ oestradiol. A $1: 200000$ dilution of antiserum in PBS bound $52 \cdot 1 \pm 2.6 \%(n=10)$ of $\left[{ }^{3} \mathrm{H}\right]$ oestradiol in the absence of unlabelled hormone. Antibody-bound and free hormone were separated by centrifugation after the addition of $200 \mu \mathrm{l}$ aliquots of dextran-coated charcoal (6.25 $\mathrm{g}$ Norit $\mathrm{A}$ and $0.62 \mathrm{~g}$ dextran T70/1 PBS) 
after overnight incubation and the bound fraction counted as in the progesterone RIA (Furr, 1973). Major cross-reactants (calculated as the amount of hormone giving $50 \%$ inhibition of binding, oestradiol- $17 \beta=100 \%$ ) with this antiserum are 16 -epioestradiol $(12 \cdot 2 \%)$, oestrone $(10.0 \%)$, oestriol $(1.4 \%)$ and oestradiol- $17 \alpha(0.5 \%)$. Assay blanks consistently produced less displacement of $\left[{ }^{3} \mathrm{H}\right]$ oestradiol than the lowest standard employed, i.e. $<1.99 \mathrm{ng} / \mathrm{ml}$. The coefficients of variation within and between assays were 8.1 and $14.9 \%$ respectively, using a pool of plasma containing an estimated $244 \cdot 0 \pm 12 \cdot 1 \mathrm{pg}$ oestrogen $/ \mathrm{ml}$. Oestradiol $-17 \beta$ added to a pool $(50-500 \mathrm{pg} / \mathrm{ml})$ of plasma was quantitatively recovered (equation of linear regression $y=$ $0.84 x+9.95 ; r=0.987)$. Sensitivity of the assay $\left(B / B_{o}=90 \%\right)$ was $21.7 \mathrm{pg}$ oestradiol $/ \mathrm{ml}$.

$L H$. Plasma LH concentrations were estimated by the homologous double-antibody radioimmunoassay of Niswender, Reichert \& Zimmerman (1970). The anti-porcine LH serum $(50 \mu \mathrm{l})(566-12 / 21$; supplied by $\mathrm{Dr}$ G. D. Niswender) diluted in radioimmunoassay diluent (RIAD) (McNeilly, McNeilly, Walton \& Cunningham, 1976) and $50 \mu$ l normal rabbit serum (NRS; diluted 1:300 in RIAD) were added to $200 \mu \mathrm{l}$ aliquots of sample plasmas or porcine LH standard (LER-778-4; supplied by Dr L. E. Reichert) and incubated for $24 \mathrm{~h}$ at $4{ }^{\circ} \mathrm{C}$. Then approximately 10000 c.p.m. ${ }^{125} \mathrm{I}$-labelled porcine LH (LER-786-3, also provided by Dr L. E. Reichert, and labelled by the method of Walton et al., 1977), were added in $50 \mu \mathrm{l}$ RIAD and incubation was continued for $24 \mathrm{~h}$. Donkey anti-rabbit $\gamma$-globulin (50 $\mu \mathrm{l})$ (RD-17; Burroughs-Wellcome, Beckenham, U.K., diluted 1:30 in RIAD) was added and after incubation for a further $24 \mathrm{~h}$ antibody-bound and free labelled hormone were separated by centrifugation $(800 \mathrm{~g}$ for $30 \mathrm{~min})$. The precipitated bound fraction was counted in an automatic gamma counter after aspiration of the supernatant. Antiserum dilutions of $1: 18000-1: 25000$ bound $20.9 \pm 0.8 \%(n=9)$ of labelled LH in the absence of unlabelled hormone. Sensitivity of the assay $\left(B / B_{0}=90 \%\right)$ was $0.18 \mathrm{ng} \mathrm{LH} / \mathrm{ml}$. Luteinizing hormone added to a pool of plasma $(0.62-2.5 \mathrm{ng} / \mathrm{ml}$ ) was quantitatively recovered (equation of linear regression $y=0.88 x-$ $0.014 ; r=0.88$ ). Within- and between-assay coefficients of variation were 9 and $18 \%$ respectively.

FSH. Plasma FSH concentrations were determined by the heterologous double-antibody radioimmunoasay of McNeilly et al. (1976). Anti-human FSH serum M94 (provided by Dr W. R. Butt and Dr S. Lynch) diluted 1:2500-1:4000 in RIAD bound $29.9 \pm 1.4 \%(n=6)$ of ${ }^{125}$ I-labelled rat FSH (NIAMDD-rFSH-I-1; labelled by the method of Walton et al., 1977) in the absence of unlabelled hormone. Ovine FSH (NIH-FSH-S8) and porcine FSH (NIH-FSH-P2) standards were used in each assay, and were equipotent in inhibiting binding. Serial dilutions of a saline extract of 2 porcine pituitary glands in RIAD gave a parallel dilution curve, as did serial dilutions of $200 \mu \mathrm{l}$ aliquots of plasma. Cross-reactivities of porcine LH (LER-778-4) and prolactin (SP 162C) were $2.92 \%$ and $0.01 \%$ respectively. No marked changes in FSH concentrations were recorded in 2 gilts bled at 15 -min intervals following the administration of $12.5 \mu \mathrm{g}$ thyrotrophin-releasing hormone (Roche) via cardiac catheters, suggesting that TSH does not interfere in the measurement of FSH in this assay. Sensitivity of the assay $\left(\mathrm{B} / \mathrm{B}_{\mathrm{o}}=\right.$ $90 \%$ ) was $7.4 \mathrm{ng} \mathrm{NIH-FSH}-\mathrm{P} 2 / \mathrm{ml}$. Porcine FSH added to a pool of plasma $(10-50 \mathrm{ng} / \mathrm{ml})$ was quantitatively recovered (equation of linear regression $y=1.04 x+2 \cdot 88 ; r=0.903$ ). Withinand between-assay coefficients of variation were 14.4 and $15 \cdot 2 \%$ respectively.

\section{Results}

All experimental sows farrowed normally within 3 days of the predicted farrowing date (117 days after service), and delivered $11.0 \pm 0.7$ (s.e.m.) piglets/litter, of which $9.7 \pm 0.9$ were born alive (see Table 1). 
Table 1. Composition of experimental groups, farrowing performance and occurrence of subsequent oestrus

\begin{tabular}{|c|c|c|c|c|c|c|c|}
\hline \multirow[b]{3}{*}{ Sow } & \multirow[b]{3}{*}{ Parity } & \multirow{3}{*}{$\begin{array}{l}\text { Post-partum } \\
\text { wt (kg) }\end{array}$} & \multicolumn{2}{|c|}{ No. of piglets } & \multirow{2}{*}{\multicolumn{3}{|c|}{ Days to oestrus* }} \\
\hline & & & & & & & \\
\hline & & & at farrowing & allocation & Farr.-Oe & $\mathrm{Gp}-\mathrm{Oe}$ & Wean-Oe \\
\hline \multicolumn{8}{|c|}{ Sows individually housed (Group I) } \\
\hline 165 & 10 & 243 & $10(+1)$ & 10 & & - & $30 \dagger$ \\
\hline 219 & 7 & 204 & $10(+3)$ & 6 & & - & 4 \\
\hline 248 & 4 & 187 & 11 & 10 & & - & 一 \\
\hline 255 & 4 & 206 & $10(+1)$ & 8 & & - & 7 \\
\hline 283 & 3 & 205 & 10 & 10 & & - & 3 \\
\hline \multicolumn{8}{|c|}{ Sows grouped (Group II) } \\
\hline 140 & 11 & 223 & $11(+1)$ & 11 & 21 & 7 & - \\
\hline 174 & 10 & 223 & $7(+3)$ & 7 & 34 & 18 & - \\
\hline 211 & 7 & 221 & $3(+3)$ & 6 & 33 & 13 & - \\
\hline 212 & 7 & 174 & 13 & 11 & 33 & 13 & - \\
\hline 242 & 4 & 191 & $12(+1)$ & 10 & 27 & 6 & - \\
\hline
\end{tabular}

\footnotetext{
* Farr-Oe = farrowing to oestrus; $\mathrm{Gp}-\mathrm{Oe}=$ grouping to oestrus; Wean-Oe $=$ weaning to oestrus.

$\dagger$ Culled from herd at 42 days (Sow 165) and 23 days (Sow 248) after weaning.
}

\section{Hormone profiles in late pregnancy and the early post-partum period}

Gonadotrophins. Plasma LH concentrations were below detectable levels $(0.18 \mathrm{ng} / \mathrm{ml})$ in most samples taken during late pregnancy and in the first 11 days post partum. In only one sow (No. 212) was LH consistently detectable in this period, when concentrations of up to 0.75 $\mathrm{ng} / \mathrm{ml}$ plasma were found (Text-fig. 1).

There was considerable variation in plasma FSH concentrations amongst and within individuals. In general, plasma concentrations were within the range $20-105 \mathrm{ng} / \mathrm{ml}$ throughout the pre- and post-partum period to Day 11. In several animals, however, a slight fall in circulating FSH was recorded from Day 3 pre partum to Day 5 post partum, with a subsequent rise to levels seen in late pregnancy levels from Day 6 (see hormone profiles for Sows 211 and 242 in Text-fig. 1).

Steroid hormones. Progesterone concentrations in late pregnancy $(8-13 \mathrm{ng} / \mathrm{ml})$ fell 1 or 2 days before parturition, reaching $1.5-3 \mathrm{ng} / \mathrm{ml}$ on the day of farrowing. Thereafter, plasma progesterone concentrations were low, and ranged between 0.3 and $1.4 \mathrm{ng} / \mathrm{ml}(0.9 \pm 0.1 ; n=$ 36) during the first 11 days post partum. Plasma oestrogen concentrations rose during the final 7 days pre partum from $150-360 \mathrm{pg} / \mathrm{ml}$ to reach $275-650 \mathrm{pg} / \mathrm{ml}$ on the last day of gestation, but fell abruptly after expulsion of piglets and placentae to $35-100 \mathrm{pg} / \mathrm{ml}$. Oestrogen titres remained low $(20-60 \mathrm{pg} / \mathrm{ml}$ plasma $)$ in the early post-partum period.

\section{Hormone profiles in sows of Groups I and II}

None of the sows in Group I exhibited oestrus during lactation. Three returned to oestrus within 7 days of weaning (which took place at $41 \pm 1 \cdot 1$ days). The remaining sows of Group I were culled from the herd 42 (Sow 165) and 23 (Sow 248) days after weaning because of poor body condition

All sows of Group II came into oestrus during lactation. The period from grouping ( 1 day before introduction of the boar) to onset of oestrus varied from 6 to 18 days $(11.4 \pm 2.5$ days).

Gonadotrophins. No evidence was obtained of an acute gonadotrophin response to the trauma of movement from the farrowing shed. Neither plasma LH nor FSH concentrations 


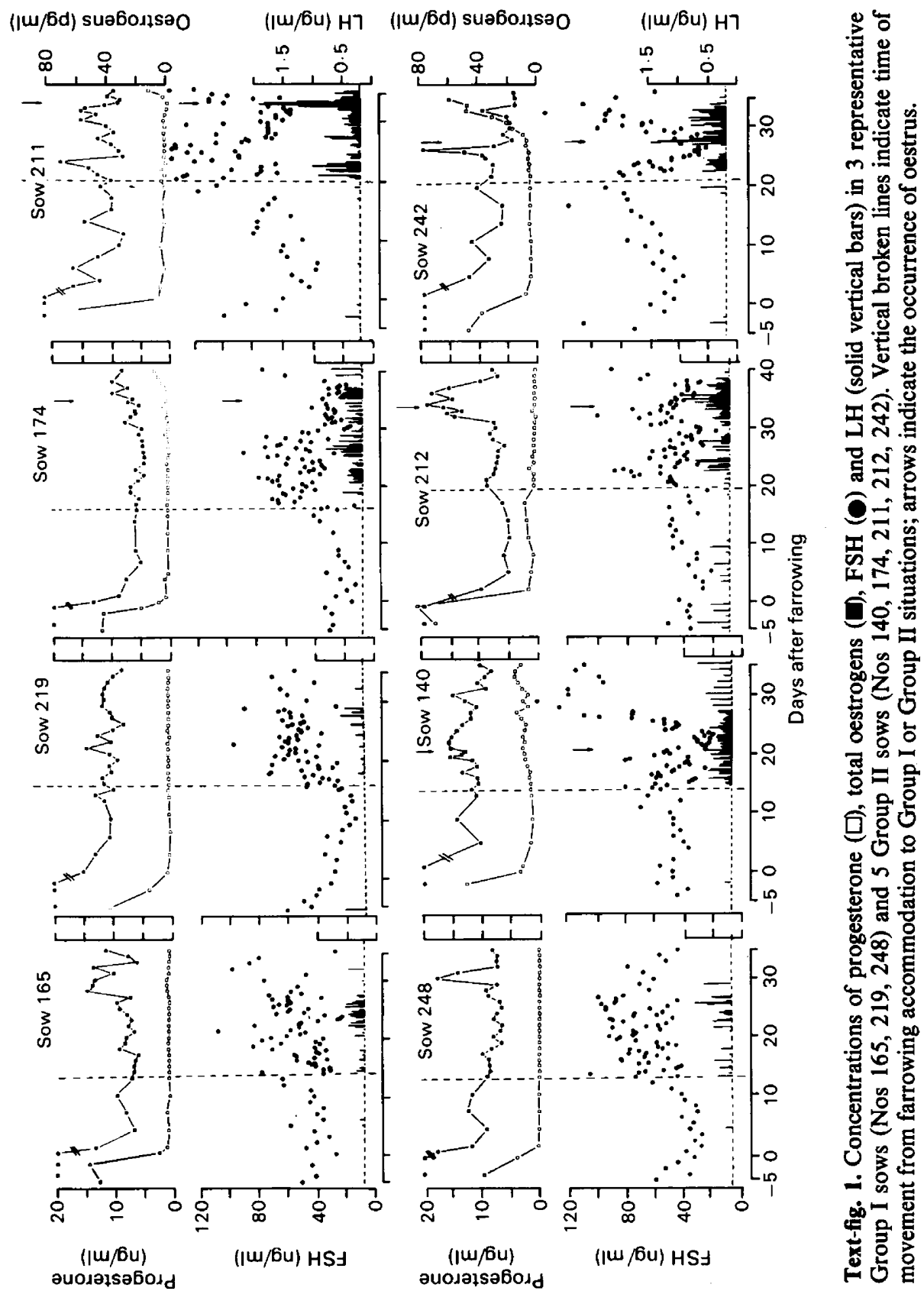


showed a marked rise or fall when comparing samples taken 20 min before and after movement of 5 sows to the Group II situation. In 2 additional sows, sampled 3 times at 15 -min intervals before and 4 times after movement from the farrowing shed, LH was below detectable levels in all of the samples from one sow and remained at concentrations of $0.35-0.47 \mathrm{ng} / \mathrm{ml}$ in the other.

Movement of sows from the farrowing shed did appear to be associated with an eventual increase in the plasma LH concentrations in both groups, although the increased frequency of sampling at this time makes a comparison of $\mathrm{LH}$ concentrations before and after the change difficult. In the sows of Group II the number of plasma samples taken at 12:00 $\mathrm{h}$ which contained measurable amounts of LH increased significantly $(P<0.01$; Student's $t$ test) from a mean of $2.0 \pm 0.8$ (s.e.m., $n=5$ ) in the 10-day period before movement to $7.2 \pm 0.7$ in the subsequent 10-day period. Corresponding figures for sows of Group I showed a smaller, non-significant increase following movement (from $1.4 \pm 0.6$ to $3.2 \pm 1.4 ; n=5$ ). Peaks of plasma LH coincident with oestrus were recorded in only 2 sows of Group II (Sow 211, 1.9 $\mathrm{ng} / \mathrm{ml}$; Sow $242,1.45 \mathrm{ng} / \mathrm{ml}$ ).

Plasma FSH concentrations rose 12-20 days post partum in 3 out of 5 sows in each group (see Sows 174, 211, 212, 219, 242, 248 in Text-fig. 1), but fell markedly over a period of 2-3 days in Group II sows before or around the time of oestrus. The values then returned to levels similar to, or higher than, those recorded immediately before oestrus. In Sows 211 and 242, maximum concentrations of 185 and $220 \mathrm{ng} \mathrm{FSH} / \mathrm{ml}$ were observed, and followed the observed peaks of LH by 48 and $126 \mathrm{~h}$ respectively.

Steroid hormones. In Group I sows progesterone concentrations remained low $(0 \cdot 23-1 \cdot 1$ $\mathrm{ng} / \mathrm{ml}$ plasma) and fluctuated little throughout lactational anoestrus. Oestrogen concentrations however, fluctuated more widely, but clear periods of raised values were evident in Sows 165 (Days 23 and 32) and 248 (Days 30 and 31) in Group I (Text-fig. 1).

Plasma oestrogen concentrations were more variable in sows of Group II. In Sow 242, a clear oestrogen peak of $76 \mathrm{pg} / \mathrm{ml}$ occurred $18 \mathrm{~h}$ before the ovulatory LH surge, coinciding with the trough in FSH concentration noted above. Plasma progesterone rose steeply after oestrus in this sow, from a basal level of $\sim 0.6 \mathrm{ng} / \mathrm{ml}$ to reach $14 \mathrm{ng} / \mathrm{ml}$ within 7 days. An elevated oestrogen concentration was also associated with the occurrence of oestrus in Sow 212 (this animal showed a mucous plug and riding marks) but progesterone remained basal $(\sim 0.8 \mathrm{ng} / \mathrm{ml})$ after oestrus. Sows 140,174 and 211 also exhibited oestrus, but with equivocal rises in plasma oestrogen concentration. Plasma progesterone concentrations rose only very slowly following oestrus in Sows 140 and 174; a rapid rise is suggested in Sow 211 but the catheter failed at this time and no further samples were taken.

\section{Discussion}

Peripheral progesterone concentrations, primarily of ovarian origin in the sow (Day, Anderson, Emmerson, Hazel \& Melampy, 1959), fell steadily in the last 3-4 days of pregnancy to reach low values by 1 day post partum. These low values were maintained during early lactation. Plasma concentrations of total oestrogen, primarily of placental or fetal-placental origin (Fevre, Leglise \& Rombauts, 1968; Ash \& Heap, 1975), fell sharply at the time of parturition to reach, by the 2 nd day post partum, the low levels recorded in early lactation. These observations are in close agreement with those reported by Molokwu \& Wagner (1973), Ash \& Heap (1975) and Baldwin \& Stabenfeldt (1975). Plasma LH concentrations were low during the last 5 days of pregnancy and during early lactation. Parvizi et al. (1976) recorded episodic releases of LH when sows were sampled at 20-min intervals in late pregnancy and correlated LH surges with changes in plasma progesterone concentrations. Plasma LH was also low during early lactation (Parvizi et al., 1976).

The estimates of plasma FSH concentrations determined using the heterologous RIA 
described are considerably higher than those reported using homologous assays (Rayford, Brinkley, Young \& Reichert, 1974; Vandalem et al., 1979), but the porcine FSH standards used in the homologous assays, however, were of considerably higher biological potency than the standard employed here $(20 \times$ and $18 \times$ NIH-FSH-P1, respectively). Plasma FSH concentrations, whilst fluctuating between samples taken from the same sow, were maintained or fell slightly in the days approaching and during the 4-5 days following parturition.

Movement from the farrowing shed of sows and litters was associated with increased plasma gonadotrophic activity in both groups. The increased frequency of blood sampling adopted after the change may have contributed to the apparent increase in gonadotrophin concentration in that the likelihood of sampling soon after the episodic release of hormone from the pituitary was increased. In 6 of the 10 sows, however, plasma FSH concentrations rose around the time of movement (Sows 174, 211, 212, 219, 248, 255), but whilst the onset of the rise closely followed movement in Sows 174, 219 and 255, the rise had already started before the movement in Sows 211 and 248. The cause of rising FSH concentrations with the stress of movement per se is therefore not established, and the possibility remains that FSH concentrations may rise spontaneously during this period (i.e. 12-20 days post partum) for reasons unrelated to the experimental manipulations.

Plasma concentrations of oestrogen and progesterone showed little fluctuation in Group I sows which suggests that the ovaries are relatively quiescent during lactational anoestrus. Morphological studies of the ovaries of lactating sows have shown a marked lack of follicular growth and an absence of corpora lutea (Palmer et al., 1965; Crighton \& Lamming, 1969), and the oestrogen and progesterone concentrations reported here accord well with earlier published data for lactating sows (Molokwu \& Wagner, 1973; Ash \& Heap, 1975; Baldwin \& Stabenfeldt, 1975; Parvizi et al., 1976). Crighton \& Lamming (1969) suggested that pituitary FSH release, but not synthesis, is inhibited during lactational anoestrus, whilst both synthesis and release of LH are inhibited, but they were unable to measure circulating gonadotrophins at that time. Whilst plasma LH concentrations were low in all samples taken in Group I sows, plasma FSH concentrations in these sows were maintained throughout anoestrus at levels wholly comparable to those in Group II sows that exhibited oestrus. Furthermore, that some limited follicular development is possible during late lactation is indicated by the period of sustained oestrogen elevation in at least 2 of our anoestrous sows. It would therefore appear that synthesis and release of FSH is possible during lactational anoestrus but that follicular development in response to FSH is inhibited, at least in early lactation, and is presumably a suckling-associated phenomenon.

In contrast to the continued lactational anoestrus of Group I sows, all animals in Group II exhibited oestrus during lactation, although the time of onset of oestrus from grouping and the endocrine events of lactational oestrus differed markedly between sows. The additional social stimuli of grouping and boar presence experienced in Group II sows, both of which appear independently to increase the proportion of sows displaying lactational oestrus (Rowlinson \& Bryant, 1976), resulted in an increased frequency of detectable LH concentrations in 6-h samples compared with those in Group I sows, but there were no obvious differences in plasma FSH profiles. In Group II, only Sow 242 eventually farrowed to service at the lactational oestrus: oestrus of this sow was characterized by a pronounced decline in plasma gonadotrophin concentrations only 2 days after movement to the experimental group, and was coincident with a marked rise in plasma oestrogen concentration. An ovulatory surge of LH followed the maximum recorded oestrogen concentration by $18 \mathrm{~h}$ at about the onset of oestrus. Plasma FSH concentration rose to reach the highest recorded level 5 days after the $\mathrm{LH}$ surge. The occurrence of ovulation and formation of corpora lutea were indicated by the steep rise in plasma progesterone that began 2 days after the LH surge, and the levels had exceeded those of late pregnancy after a further 3 days. These data are in good agreement with those reported for cyclic sows at oestrus (Niswender et al., 1970; Tilson et al., 1970; Rayford, Brinkley \& Young, 
1971; Henricks et al., 1972; Wilfinger, Brinkley \& Young, 1973a, b; Rayford et al., 1974; Parvizi et al., 1976; Vandalem et al., 1979) and those for the post-weaning oestrus (Ash \& Heap, 1975; van de Wiel, van Landeghem, Willemse \& Bevers, 1979). Sow 211 displayed a very similar, but delayed, sequence of events leading to an ovulatory oestrus 13 days after grouping, but returned to oestrus 22 days later. The remaining 3 sows of Group II all exhibited lactational oestrus, but did not conceive. Plasma oestrogen concentrations were elevated for a period of 6 days in Sow 212, during which oestrus occurred. No discrete LH surge was detected and plasma progesterone data confirmed that ovulation did not take place. The slow rises of plasma progesterone in Sows 140 and 174 following oestrus suggest that ovulation, if it took place at all, was atypical. This apparent failure to ovulate normally in our experimental group situation may explain the lower success rate observed in our herd compared with previous findings from a commercial herd (Rowlinson \& Bryant, 1975).

Nevertheless, the social stimuli of grouping sows with litters and boar presence are clearly able to overcome those factors associated with lactation that normally result in a prolonged state of anoestrus. Observations of nursing and suckling behaviour indicate that grouping has little effect on the frequency and duration of nursing (Bryant, Rowlinson \& Van der Steen, 1974), but no data are available on plasma prolactin concentrations about the time of lactational oestrus. Plasma prolactin concentrations are high in the sow during lactation and dependent upon continued suckling (Brinkley, Rayford \& Young, 1972; Bevers, Willemse \& Kruip, 1978; van de Wiel et al., 1979), and fall rapidly after weaning (Bevers et al., 1978; van de Wiel et al., 1979). Whilst lactation is not impaired by ovariectomy of the sow (Crighton \& Lamming, 1969), the rises in pituitary LH content and plasma LH concentration that follow ovariectomy of a cyclic or non-lactating sow are absent (Crighton \& Lamming, 1969; Parvizi et al., 1976). Plasma LH does rise, however, in entire and ovariectomized sows following weaning (Parvizi et al., 1976). These data have been interpreted as indicative of an impaired negative feedback of gonadal steroids on pituitary function during lactation (Parvizi et al., 1976; Elsaesser \& Parvizi, 1980). Weaning is characterized by rapid follicular growth between cessation of suckling and oestrus, and accompanying uterine changes are indicative of oestrogen production (Crighton \& Lamming, 1969). The resumption of ovarian function after weaning may therefore be associated with a release from inhibition of $\mathrm{LH}$ secretion and ovarian response to circulating FSH following removal of the suckling stimulus. A progressive escape from the inhibition occurs with duration of suckling (Polge, 1972). Elsaesser \& Parvizi (1980) demonstrated that the normal positive feedback of injected oestrogen on plasma LH (see Foxcroft, 1978) is absent in early lactation but has partly recovered after 5 weeks, and suggests that such a recovery may be correlated with the progressive decline of plasma prolactin levels seen from parturition to weaning (van Landeghem \& van de Wiel, 1978). This progressive escape from inhibition with duration of lactation presumably explains the signs of follicular development observed in 2 sows in Group I.

The mechanisms whereby social stimuli induce a resumption of ovarian activity in the lactating sow remain unknown but deserve further attention, since their elucidation will make an important contribution to our understanding of reproductive physiology in the pig.

We thank Dr B. J. A. Furr for the antisera to progesterone and oestradiol-17ß; Dr L. E. Reichert for purified porcine LH; Dr G. D. Niswender for antiserum to porcine LH; Miss Jane Morgan and Mrs J. Evins for assistance with hormone assays; and Dr J. S. Walton for assistance in surgery. The study was conducted during the tenure of an Agricultural Research Council Post-Doctoral Fellowship by R.T.D.

\section{References}

Anderson, D.M. \& Elsley, F.W.H. (1969) A note on the use of indwelling catheters in conscious adult pigs. $J$. agric. Sci., Camb. 72, 475-477.
Ash, R.W. \& Heap, R.B. (1975) Oestrogen, progesterone and corticosteroid concentrations in peripheral plasma of sows during pregnancy, 
parturition, lactation and after weaning. J. Endocr. 64, 141-154.

Ash, R.W., Banks, P., Broad, S. \& Heap, R.B. (1972) Techniques for studying changes in some peripheral blood components and steroid hormones in pregnant and lactating sows. J. Physiol., Lond. 226, 40P-41P, Abstr.

Baldwin, D.M. \& Stabenfeldt, G.H. (1975) Endocrine changes in the pig during late pregnancy, parturition, and lactation. Biol. Reprod. 12, 508-515.

Bevers, M.M., Willemse, A.H. \& Kruip, Th.A.M. (1978) Plasma prolactin levels in the sow during lactation and the post-weaning period as measured by radioimmunoassay. Biol. Reprod. 19, 628-634.

Boughton, H.G. (1967) Mum helps herself. Pig Farming 15, 24-25.

Brinkley, H.J., Rayford, P.L. \& Young, E.P. (1972) Porcine prolactin radioimmunoassay. J. Anim. Sci. 35, 237, Abstr.

Bryant, M.J., Rowlinson, P. \& Van der Steen, H.A.M. (1974) Rebreeding sows during lactation II. A comparison of nursing and suckling behaviour between single and group-housed sows. Proc. 3 rd Int. Congr. Int. Pig Vet. Soc. Lyons C6, 1-5.

Crighton, D.B. (1970) Induction of pregnancy during lactation in the sow. J. Reprod. Fert. 22, 223-231.

Crighton, D.B. \& Lamming, G.E. (1969) The lactational anoestrus of the sow; the status of the anterior pituitary-ovarian system during lactation and after weaning. J. Endocr. 43, 507-519.

Day, B.N., Anderson, L.L., Emmerson, M.A., Hazel, L.N. \& Melampy, R.M. (1959) Effect of estrogen and progesterone on early embryonic mortality in ovariectomized gilts. J. Anim. Sci. 18, 607-613.

Dusza, L. \& Krzymowska, H. (1979) Plasma prolactin concentrations during the oestrous cycle of sows. $J$. Reprod. Fert. 57, 511-514.

Elsaesser, F. \& Parvizi, N. (1980) Partial recovery of the stimulatory oestrogen feedback action on LH release during late lactation in the pig. J. Reprod. Fert. 59, 63-67.

Fevre, J., Leglise, P.C. \& Rombauts, P. (1968) Du rôle de l'hypophyse et des ovaires dans la biosynthèse des oestrogènes au cours de la gestation chez la truie. Annls Biol. anim. Biochim. Biophys. 8, 225-233.

Foxcroft, G.R. (1978) The development of pituitary gland function. In Control of Ovulation, pp. 117138. Eds D. B. Crighton, G. R. Foxcroft, N. B. Haynes \& G. E. Lamming. Butterworths, London.

Furr, B.J.A. (1973) Radioimmunoassay of progesterone in peripheral plasma of the domestic fowl in various physiological states and in follicular venous plasma. Acta endocr., Copenh. 72, 663-674.

Heitman, H. \& Cole, H.H. (1956) Further studies on the induction of estrus in lactating sows with equine gonadotrophin. J. Anim. Sci. 15, 970-977.

Henricks, D.M., Guthrie, H.D. \& Handlin, D.L. (1972) Plasma estrogen, progesterone, and luteinizing hormone levels during the estrous cycle of pigs. Biol. Reprod. 6, 210-218.

Holness, D.H. \& Hunter, R.H.F. (1975) Post-partum oestrus in the sow, in relation to the concentration of plasma oestrogens. J. Reprod. Fert. 45, 15-20.

Lauderdale, J.W., Kirkpatrick, R.L., First, N.L., Hauser, E.R. \& Casida, L.E. (1965) Ovarian and pituitary gland changes in periparturient sows. J. Anim. Sci. 24, 1100-1103.

McNeilly, J.R., McNeilly, A.S., Walton, J.S. \& Cunningham, F.J. (1976) Development and application of a heterologous radioimmunoassay for ovine follicle-stimulating hormone. J. Endocr. 70, 69-79.

Molokwu, E.C.I. \& Wagner, W.C. (1973) Endocrine physiology of the puerperal sow. J. Anim. Sci. 36, 1158-1163.

Niswender, G.D., Reichert, L.E. \& Zimmerman, D.R. (1970) Radioimmunoassay of serum levels of luteinizing hormone throughout the estrous cycle in pigs. Endocrinology 87, 576-580.

Palmer, W.M., Teague, H.S. \& Venzke, W.G. (1965) Macroscopic observations on the reproductive tract of the sow during lactation and early post-weaning. J. Anim. Sci. 24, 541-545.

Parvizi, N., Elsaesser, F., Smidt, D. \& Ellendorfi, F. (1976) Plasma luteinizing hormone and progesterone in the adult female pig during the oestrous cycle, late pregnancy and lactation, and after ovariectomy and pentobarbitone treatment. J. Endocr. 69, 193-203.

Petchey, A.M. \& Jolly, G.M. (1979) Sow service in lactation: an analysis of data from one herd. Anim. Prod. 29, 183-191.

Phelps, A. (1969) Batched sows served while suckling. Pig Farming 17, 46-47.

Polge, C. (1972) Reproductive physiology in the pig with special reference to early weaning. Proc. Br. Soc. Anim. Prod. 1, 5-18.

Rayford, P.L., Brinkley, H.J. \& Young, E.P. (1971) Radioimmunoassay determination of LH concentration in the serum of female pigs. Endocrinology 88, 707-713.

Rayford, P.L., Brinkley, H.J, Young, E.P. \& Reichert, L.E. (1974) Radioimmunoassay of porcine FSH. $J$. Anim. Sci. 39, 348-354.

Rowlinson, P. \& Bryant, M.J. (1975) The effect of the interval between farrowing and grouping on the incidence and timing of oestrus in sows during lactation. Proc. Br. Soc. Anim. Prod. 4, 103-104.

Rowlinson, P. \& Bryant, M.J. (1976) The effect of lactation management on the incidence and timing of oestrus in lactating sows. Anim. Prod. 22, 139.

Rowlinson, P., Boughton, H.G. \& Bryant, M.J. (1975) Mating of sows during lactation; observations from a commercial unit. Anim. Prod. 21, 233-241.

Smith, D.M. (1961) The effect of daily separation of sows from their litters upon milk yield, creep intake and energetic efficiency. N.Z. J. agric. Res. 4, 232-245.

Stabenfeldt, G.H., Akins, E.L., Ewing, L.L. \& Morrissette, M.C. (1969) Peripheral plasma progesterone levels in pigs during the oestrous cycle. $J$. Reprod. Fert. 20, 443-449.

Tilson, S.A., Erb, R.E. \& Niswender, G.D. (1970) Comparison of luteinizing hormone and progesterone in blood and metabolites of progesterone in urine of domestic sows during the estrous cycle and early pregnancy. J. Anim. Sci. 30, 795-805.

Vandalem, J.L., Bodart, C.R., Pirens, G., Closset, J. \& Hennen, G. (1979) Development and application of homologous radioimmunoassays for porcine gonadotrophins. J. Endocr. 81, 1-10.

van de Wiel, D.F.M., van Landeghem, A.A.J., Willemse, 
A.H. Bevers, M.M. (1979) Endocrine control of ovarian function after weaning in the domestic sow. J. Endocr. 80, 69P, Abstr.

van Landeghem, A.A.J. \& van de Wiel, D.F.M. (1978) Radioimmunoassay for porcine plasma prolactin levels during lactation, suckling and weaning and after TRH administration. Acta endocr., Copenh. 88, 653-657.

Walton, J.S., McNeilly, J.R., McNelly, A.S. \& Cunningham, F.J. (1977) Changes in concentrations of follicle-stimulating hormone, luteinizing hormone, prolactin and progesterone in the plasma of ewes during the transition from anoestrus to breeding activity. J. Endocr. 75, 127-136.

Waifinger, W.W., Brinkley, H.J. \& Young, E.D. (1973a) Plasma LH in the estrous cycle of the pig. J. Anim. Sci. 37, 333, Abstr.

Wilfinger, W.W., Brinkley, H.J. \& Young, E.D. (1973b) Plasma FSH in the estrous cycle of the pig. J. Anim. Sci. 37, 333, Abstr.

Received 24 March 1981 